\section{Welfare of Aliens}

AN Advisory Council of Aliens has been appointed by the Secretary of State for Foreign Affairs. This Council, which is under the chairmanship of Lord Lytton, and will work in close association with the Foreign Office and other departments concerned, will advise the Home Office on the general welfare of interned aliens, make recommendations on finding employment for internees, and suggest measures for maintaining their morale and binding them more closely to the cause for which Great Britain is fighting.

A Home Office White Paper (Cmd. 6217. London : H.M. Stationery Office. 1d.) has been ișsued showing the conditions under which German and Austrian refugees at present interned may be released. The regulations now issued apply only to "C Class" internees, but it is stated that they are not to be regarded as final. Among those who may now apply for release are those who occupied key positions in industries engaged in work of national importance, skilled workers in agriculture, commercial foodgrowing and forestry, and scientific and other research workers and persons generally with academic qualifications for whom national work in their own fields is available. With regard to the latter groups, special committees are being set up by the vicechancellors of the universities, the Royal Society and the British Academy to consider applications and to submit recommendations to the Home Secretary. These new regulations seem to provide the necessary safeguards of national security required in any relaxation of the order for general internment of aliens, and should meet with general approval.

\section{An International Labour Force}

SPEAKING in the House of Commons on August 1, Mr. Bevin, Minister of Labour, announced that he has set up an International Labour Branch as part of the employment department of his Ministry. The purpose of this branch is to organize the man-power of allied nations and of other well-disposed persons of foreign nationality in Great Britain. It is hoped to obtain full knowledge of those available for employment and to seek suitable openings for them in industrial and other work. Co-operation is to be maintained with the Allied Governments and other national authorities in Great Britain, and Mr. Bevin also hopes to have the advice of representatives of trade unions of foreign countries. He was very emphatic that the new branch would have nothing to do with internees; release of aliens and their supervision generally is a matter for the Home Office. Once an individual has been passed by the Security Department, then he becomes available for consideration by the Ministry of Labour. At this stage, Mr. Bevin said he proposed to dispense with the terms 'aliens' and 'refugee', and to refer to such individuals as an 'International Labour Force'. This development, coming at the same time as the announcement of limited release of German and Austrian refugees, shows that the problem of dealing with the unfortunate people who have been driven from their homes by Nazi and Fascist persecution is being given careful consideration. They have come to Great Britain for freedom, and while they will recognize that the special needs of the times make restrictions of various kinds necessary, they will appreciate the opportunity which is now to be given them of taking an active part in the struggle against totalitarian domination.

\section{Sales Tax on Books and Periodicals}

THE case for withholding the imposition of the proposed purchase tax from printed books and periodicals was put before a private meeting of Members of Parliament held on August 6. As a result of the meeting, Mr. Kenneth Lindsay obtained support for an amendment which he is to submit proposing to omit printed books, music, pamphlets and leaflets from the schedule of taxable articles, and P. J. Loftus put forward another amendment which would exempt weekly, monthly and quarterly technical, scientific and trade journals retailed at not less than $6 \mathrm{~d}$. An amendment to exempt newspapers and periodicals is to be moved by Mr. Mander. Nature has already discussed the probable effects of the imposition of a sales tax on books and other publications (May 11, p. 719, and August 3, p. 160). On general as well as scientific grounds, the imposition of a tax on books is a bad thing, which even at the present time cannot be justified on grounds of financial expediency.

\section{African Studies and the War}

Lord LugARD, as chairman of the Executive Council of the International Institute of African Languages and Cultures, announces in the current issue of Africa (13, 3; July 1940) that the work of the Bureau and the publication of its periodical Africa must now cease for the duration of the War. In October last it was stated that it was hoped to carry on the Institute's work without serious interruption. Recent developments, however, have made international co-operation impossible, and it has been deemed advisable in the circumstances to cease work until after the War. Certain of the special publications of the Institute, which have proved so valuable to students of African peoples, are in an advanced stage of preparation and will be published as soon as possible-a book on African political systems, recently published by the Institute, is discussed on p. 188 of this issue of Nature. Further, several research fellows are engaged in writing up their field-notes. Dr. Nadel's notes on the Nupe of Northern Nigeria, and those of Mr. and Mrs. Krige on the Lovedu of the Northern Transvaal have been completed; but Dr. Margaret Read is still engaged on the results of her research in Nyasaland, and more especially on the part she took in the recent nutrition survey of that territory.

While those who have followed the work of the Institute, more especially since the receipt of the generous grant for field-work from the Rockefeller Trustees, will deeply regret this interruption, temporary though it may be, in its activities, they must, of course, accept the facts of the situation and realize that the international co-operation which has given 